\title{
Unggah-Ungguh Javanese Language Student of Class 1-6 SDN Gembong 04 Pati
}

\author{
Aji Tulus Prasetyo ${ }^{1}$, Purwadi ${ }^{2}$ \\ $\left\{1\right.$ ajitulus.2018@.student.uny.ac.id, ${ }^{2}$ purwadi@uny.ac.id\} \\ ${ }^{1,2}$ Universitas Negeri Yogyakarta
}

\begin{abstract}
This research observed the development of unggah-ungguh(manners) of students of State Elementary School Gembong 04 started from class 1 up to class 6 and the parties influencing which existing in the vicinity of the family, community and school. This research is aimed to discover how the development of manners/unggahungguh of the student and the role of the parties existing within the family, community, and school in influencing it. Method used was qualitative method with case study technic. The data was obtained through observation and interview technic. The result obtained from this research is the development of the unggahungguh of the student of the elementary school was influenced by the family, society and school environment. The parties in those neighborhoods have many roles to the development of the unggah-ungguh of the elementary school students. Whilst the development of the student's unggahungguh itself of every class is improving which at the beginning using a mix unggah-ungguhthen it will be more improving when he enters upper grade but also the more complex the students in using the unggah-ungguh.
\end{abstract}

Key Words:Unggah-ungguh, Javanese Language, Elementary School Students

\section{Introduction}

Education is closely related to culture, in every education there is always local content which closely related to the culture in the area. For an instance, the school education in Java, there must be local content which in the form of Javanese language. A subject teaches the students to learn and study the Javanese culture, such as speaking in a good and polite Javanese language, Javanese tradition such as respect the elders or older person than us or called unggah-ungguh basa (manners) [1], the Javanese arts such as Javanese puppets, traditional music and others, traditional clothes, Javanese letters and many more. All of them need to be taught by the teacher started from elementary school up to next level. It is not just taught, the Javanese culture also needs to be preserved since majority of Javanese community nowadays starts to leave the culture behind, this affects to them as if they are losing their identity [2], some called it "wong jowo ilang jawane (the Javanese has been losing their identity). As occurred in TanjungrejoVillage, Bayan Sub District, Purworejo District, where many kids at elementary age make a lot of mistakes in using manners to the elders [3]. Actually, we have acknowledged the Javanese culture since childhood; it is like we learn our 
language for the very first time by using our mother language,and therefore the Javanese learns the Javanese language as their mother language.

The condition of the environment also affects the ability of the children in speaking, for an instance in society or family, if in the family the child has never been taught Javanese karma but only taught Javanese ngoko definitely in the development of the kid he will use ngoko language for his communication [4], if it is used in speaking with his classmate it will be no problem, since there are no level involved. If the Javanese ngoko is used while speaking with parents, teachers and elders it will definitely a problem likely the child has no manners or unggahungguh to someone older than him, from here parent's leadership is needed [5]. In addition to the environment of the family, society also takes part. For an instance, the child resides in a village where they still preserve and speak a very polite Javanese, he definitely will grow with a very formal Javanese and well mannered. Inversely proportional if the neighborhood speaks rough language, manners will begin to fade away and the child who grow and develop in the neighborhood will speak rough language and lack of manners [6]. These matters create the school as a place to study, improve and re-introduce the real Javanese culture properly and correctly. Speaking about the school definitely will be discussing educator or student and educator or teacher. In school teacher acts as source of knowledge and the student as the subject of the knowledge receiver. Student receives what presented by the teacher in the learning process. The knowledge owned by teacher sometimes is wrong and the mistake is taught to the student, without realizing it develops by itself. In school the teacher should teach unggahungguh in a communicative manner, in order the students to be more easier to comprehend the subject [7].

The issues occurred are unggahungguh in this era suffered much degradation, notably in Pati city, Central Java. Through this research the researcher intended to study how the development of the unggahungguh in elementary school is. The reason in selecting the elementary school is because this level is the most determining in the development and growth of one's affective, cognitive and psychomotor. This research is conducted in State Elementary School Gembong 04 Gembong Sub District, Pati District, Central Java. This research is aimed to discover the development of unggahungguh and the role of the parties which might affect the development. Afterwards, from the review of the background above, the researcher will conduct a research with title "Unggah-Ungguh Javanese Language of Students of Class 1-6 SDN Gembong 04 Pati". It is expected that through this research the development of the manners of the students of elementary school class 1-6 can be discovered as well as the influence from the family, society, school,and other related parties.

\section{Research Method}

This research used qualitative research type and case study as its technic. Qualitative research is a research intended to comprehend what phenomenon suffered by the research subject such as behavior, perception, motivation, acts, etc. [8]. Collaborated with case study case technic will make this research more accurate in the phenomenon exploratory and discovery which influencing the subjects. In addition, this research also used Grounded Theory. Grounded theory is a theory obtained inductively from the research regarding the phenomenon it laid out. [9]. The data retrieval was conducted by observation and interviews. Observation is the basis of all knowledge. The scientists merely work based on data, namely facts concerning reality world retrieved from observation [10]. Interview is an activity carried 
out to retrieve information directly by asking the questions to respondent [11]. This research was conducted in SDN Gembong04. The population in the research was student of class 1-6 and interviewing the parents and surrounding community and teachers. The sampling technic used Stratified random sampling. This technic was selected since the technic retrieving the sample based on certain stratification, such as student with highest, medium, and lowest achievements. This technic was only undertaken to students. In Pati, common javanese language used were 3, variety of ngoko (VN), variety of krama (VK), and variety of krama inggil (KI), then there are language commonly used namely Bahasa Indonesia $(B I)$.

\section{Results And Discussion}

This research retrieved the data started from class 1 up to class 6 and data regarding the influence of the family, society and school. Data found in class 1, in which the student of class 1 in school still speaking with the teacher using a mix language. Mix here means between BI and $\mathrm{VN}$, as for VK only limited to words nggih-mboten:

*in front of the class*

Teacher : "ndhuk, mau mpun sarapan dereng?”. (kids have you had breakfast?)

Student : "belum bu, ibuk boten masak". (not yet mam, mother did not cook)

Teacher : "Iha kenapa ora masak?" (why did she not cook?)

Student : "gak tau bu". (i do not know mam)

Of the conversation above can be seen that the student of class 1 still uses mix language between BI and VN. From the researcher observation, it is discovered that apparently at home the student was accustomed to use BahasaIndonesia, parent accustoms their children speaking BI. Whereas in society, students of class 1 still have not blended in well, they still tended to be shy and timid around the community. At school they have been taught speaking with VK and $\mathrm{KI}$ in spite once in a while they are using BI. The use of VK and KI is conducted outside learning hours such as before learning activity (LA) started, school break and after school. Since during LA, BI is used since the function of the BI as a language needs to be used during formal activities in all institutions unless Javanese subject.

Data retrieved from the research in class 2 discovered that the conversation started with more javanese words. It can be seen on the teacher and student of class 2 following:

*At school parking lot*

Teacher : "Nang, lehmu parkir sepeda maju maneh!”. (kiddo, park your bike move forward)

Student : "nggih bu, tak tatane sek". (yes mam, i will organize it first)

Teacher : "ya, tata sing apik”. (yea, organize it well)

Student : "siap bu!".( yes mam)

This conversation indicates that the student of class 2 starts to have a self confidence in using bahasajawa. The Javanese language taught in school is started to be adopted by the student at home, which makes parents also respond the language used by the kid. Vocabulary of Javanese starts to improve due to during the learning of Javanese language little by lttlejavanese vocabulary started to be added. The students of class 2 have started to play with their friends though limited to one block neighbor (RT). At this stage the students still do not dare and frighten to speak with older beside his parent. Generally the Javanese language used by the student of class 2 include in VK [12]. 
On research of the student of class 3, the number of the vocabularies begins to increase. On a conversation of the student of class 3 with the older person or teacher sometimes uses VN type of ngokoalus, ngokoalus is a VN which in the sentence is inserted with VK. Such as what happened in following conversation:

*In teachers room*

Student : “Bu, kula ajeng golek bal ning gudang”. (Mam, I'm going to look for the ball in the warehouse)

Teacher : "iya, limang menit”. (Okay, five minutes)

Student : "nggih bu”. (Yes mam)

Of the conversation above the use of $\mathrm{VN}$ type of ngokoalus is seen in the first conversation. The use of word "ajeng" means "want to/going to". Then other words use VN. That is because at home the student barely hears VK language used by parent. The parent often speaks with VN. In society the student starts to play with his neighborhood friend however he lacks of courage in speaking with the elders. In a conversation with a friend the child always uses VN language.

Observation to class 4 , discover that the student of class 4 starts using the VK type of krama lugu. Krama lugu is a type of sentence dominated by VK and inserted with VN type of ngoko alus. It can be seen on following conversation:

*In front of class*

Teacher : "nang, sangumu piro?" (kid, how much pocket money do you have?)

Siswa : "kalihewu pak." (two thousand sir)

Guru : "arep kanggo jajan apa wae?" (What are you going to buy?)

Siswa : "ajeng kangge tuku es cemud kalihan ndog gulung pak." (I'd like to buy ice cream and egg roll sir)

Of the conversation above VK type of krama lugu is explained from the last conversation on words "tuku" which means "buy" and other words using VK. At stage class 4 many more vocabulary that has been taught at javanese lesson or outside Learning Activity hours. At this stage the children has began to understand on the use of unggah-ungguh and adopted it in their home with parent and the parent responds it well. In the vicinity of the neighborhood the student of class 4 has brave enaough to speak with older people. It is started from copying adult conversation and behavior. At this stage the copying character of the child will be increasingly influencing. School environment, community and home have become a place determining the development of the student's unggah-ungguh.

The research on student class 5 retrieved data that the class 5 student can already use VK language to older people. It is commonly used to parents, teacher, and neighbors. This can be seen on following conversation:

*In school cafe*

Student : "bu, kula ajeng tumbas sekul kalihan es teh.” (mam, i would like to buy rice and ice tea)

Seller : "iya nang, enteni sedhela ya. Iki iseh antri loro". (okay kiddo, hold on a minute ya, waiting in line two more)

Above conversation indicates that the class 5 students has a complex vocabulary in using unggah-ungguh and $V K$ language. At home they can already adopt the unggah-ungguh properly. Making a conversation with parents has also gone well. Greeting the neighbors has already common and has courage to speak to adults. The community will compliment a child 
with unggah-ungguh. With this compliment the child will be motivated to use unggah-ungguh in all situations. At school many Javanese vocabularies has been taught through Javanese lesson and its daily activities.

Research on students of class 6 , retrieved the data that the class 6 students have used to speak with VK language properly and equally as class 5 students. Only they have more vocabularies. Dare to tell a story to the teacher with many VK vocabularies and high self confidence in using greater unggah-ungguh. It can be seen on below conversation:

*In the class room*

Student : "Pak, kula gadhah pelem kathah. Menawi jenengan kersa, enjing-enjing kula bethake".(sir, I have so many mangos. If you wish, i can bring some for you)

Teacher : "iya agea ndhuk, arep digaweke pira?”. (Yea alright kid, how many mangos will you bring for me?)

Student : “nggih mangke kula matur kalih ibuk riyen pak”. (Yes sir, I will tell my mom later sir)

Teacher : “wah, iya ndhuk. Pinter ngnoe”. (well kid. You're so smart)

Student of class 6 in the vicinity of the society has used to get along with adults, such as participating in community service. In society will compliment a child with good manners and sometimes compare his son with the child. In fact, comparing should not be carried out [14]. However, in Pati area which majority is villages this is commonly conducted.

\section{Conclusion}

The development of elementary school'sunggah-ungguhis affected by family, society and school environments. Parties in the neighborhood take part in the development of the students at elementary school age. Whereas the development of the student's unggah-ungguhitself in every level of class is having an increase which initially using mix unggah-ungguhthe increase the class the more complex in using the students' unggah-ungguh. In class 1 there are still many mix language between Bahasa Indonesia, class 2 students still uses VN, class 3 uses VN type ngokoalus, class 4 uses VK type kramalugu, class 5 has used VKand class 6 uses VKwith much more vocabularies and self confidence.

\section{References}

[1] Supartinah, "Peran Pembelajaran Unggah-ungguh Bahasa Jawa Dalam Penanaman Nilai Sopan Santun Di Sekolah Dasar," Didaktika, vol. 1, no. 1, 2006.

[2] N. R. Setyaningsih, "Pengenalan Bahasa Jawa pada Anak Sebagai Bentuk Pemberdayaan Bahasa Lokal dan Upaya Penguatan Jati Diri Bangsa," Tutur Cakrawala Kaji. Bahasa-Bahasa Nusant., vol. 1, no. 1, pp. 27-36, 2015.

[3] S. Anwar, "Penggunaan Bahasa Jawa Anak Usia SD Di Desa Tanjungrejo Kecamatan Bayan Kabupaten Purworejo," Aditya, vol. 3, no. 4, pp. 36-41, 2013.

[4] H. B. Mardikantoro, "Pergeseran Bahasa Jawa Dalam Ranah Keluarga Pada Masyarakat Multibahasa Di Wilayah Kabupaten Brebes," Humaniora, vol. 19, no. 1, pp. 43-51, 2012.

[5] K. Effendi, "Kepemimpinan Orangtua dalam Mendidik Anak Melalui Unggah-ungguh Basa dan Basa Semu di Lingkungan Masyarakat," PSIKOPEDAGOGIA J. Bimbing. dan Konseling, vol. 4, no. 1, p. 31, 2015. 
[6] B. Indrayanto and K. Yuliastuti, "Fenomena Tingkat Tutur Dalam Bahasa Jawa Akibat Tingkat Sosial Masyarakat," Magistra, vol. 27, no. 91, pp. 37-44, 2015.

[7] S. Wibawa, "Faktor-Faktor Sosiollnguistik Dalam Pengajaran Unggah-Ungguh Bahasa Jawa," Cakrawala Pendidik., 1990.

[8] J.Moleong, Lexy. 2016. Metodologi Penelitian Kualitatif. Bandung. PT Remaja Rosdakarya.

[9] Anselm \& Juliet.2007. Dasar-dasar Penelitian Kualitatif. Yogyakarta: Pustaka Pelajar.

[10] Nasution. 2003. Metode Research. Jakarta: PT. Bumi Aksara.

[11] Subagyo.2015. Metode penelitian dalam teori dan Praktik. Jakarta: Rineka Cipta.

[12] A. N. Hidayati, "Penggunaan Bahasa Pertama (Bahasa Jawa) di dalam Kelas Anak Usia 7 Tahun Pada Siswa SDN Kateguhan Boyolali," Magistra, vol. 29, no. 102, pp. 1-14, 2017.

[13] A. Wijayanti, "Penguatan Karakter Siswa Melalui Penggunaan Unggah-Ungguh Bahasa Jawa," Kebudayaan, vol. 13, no. 1, p. 45, 2019.

[14] K. Saddhono and M. Rohmadi, "A Sociolinguistics Study on the Use of the Javanese Language in the Learning Process in Primary Schools in Surakarta, Central Java, Indonesia." Int. Edu. Stu., vol. 7 no.6 pp 25-30, 2014 